\title{
THE MYSTERY OF CHARLES STOTHARD, FSA, AND THE BAYEUX TAPESTRY FRAGMENT
}

\author{
Michael Lewis, FSA*
}

\begin{abstract}
In I8I6 the Society of Antiquaries of London sent Charles Stothard to Bayeux to produce a fullsize colour reproduction of the Bayeux Tapestry. During this time, plaster casts of the tapestry were made and a small fragment of the famous textile was removed. Stothard's wife, Eliza, was accused of looting the fragment, but was later absolved. So who was the thief? This paper examines the mystery of Charles Stothard and the Bayeux Tapestry fragment.
\end{abstract}

On Monday 8 July I8I6, the Council of the Society of Antiquaries 'ordered' that its historical draughtsman, ${ }^{\mathrm{I}}$ Charles Stothard, 'be directed to make drawings of the Bayeux Tapestry during the summer ... for the use of the Society'; ${ }^{2}$ perhaps it was no coincidence that four days earlier Hudson Gurney, FSA, a former member of Council, 'communicated to the Society some remarks concerning the Bayeux Tapestry', ${ }^{3}$ subsequently published in Archaeologia. ${ }^{4}$ By this time English antiquarians had become increasingly interested in the famous embroidery, convinced - to the indignation of French scholars - that it was originally worked in England and that French drawings of it, most notably those of 1729-30 commissioned by Bernard de Monfaucon, ${ }^{5}$ were 'insufficient' for the purpose of academic study.

In September I8I6 Charles Stothard left for the Hôtel de Ville, Bayeux, to illustrate the tapestry. ${ }^{6}$ Stothard visited Bayeux on a further two occasions, once returning with his wife, Eliza, to make a full-size colour reproduction. His work was completed by March I8I9, at a cost to the Society of $£ 559$ igs $6 \mathrm{~d} .{ }^{7}$ Thereafter, he oversaw the engraving of a one-third size facsimile, reproduced as seventeen plates in the sixth volume of Vetusta Monumenta, published by the Society (fig I). ${ }^{8}$ Five hundred handcoloured prints of the first plate were produced, ${ }^{9}$ which Fellows could purchase at Ios each. ${ }^{\text {I0 }}$ Sadly, Stothard never saw the end of the project: on 28 May I82 I he was killed after falling from a ladder whilst tracing a stained-glass window at St Andrew's Church, Beer Ferrers, Devon.

While in Bayeux, Stothard also made plaster casts of certain details of the tapestry; three of these casts, now on one piece of plaster, are in the British Museum (fig 2), and another is housed in the collections of the Society of Antiquaries (fig 3). ${ }^{\text {II }}$ Stothard's methods, by modern standards, were primitive: he pressed wax into areas of the linen and then peeled them off. These produced moulds from which he made the plaster casts. They were then painted to resemble the colours of the original.

* M $\mathcal{F}$ Lewis, Department of Portable Antiquities and Treasure, British Museum, Great Russell Street, London $W C_{I} B{ }_{3} D G$, $U K$.

E-mail:<mlewis@thebritishmuseum.ac.uk>. 


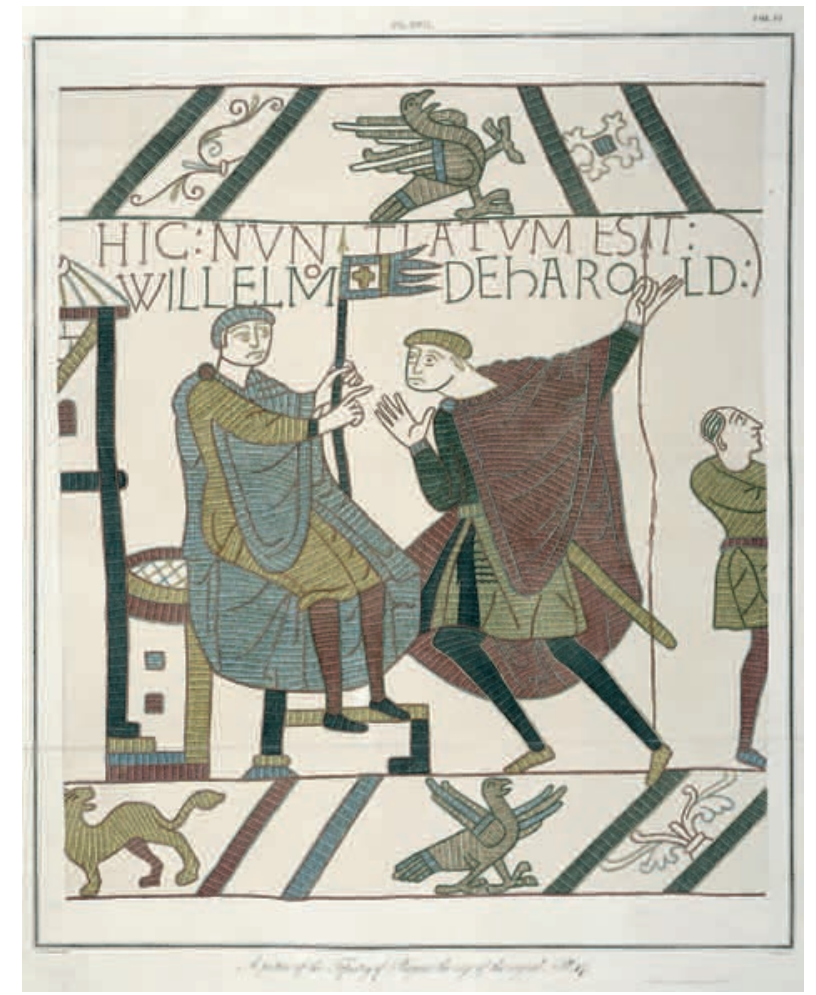

Fig I. Engraving of the Bayeux Tapestry by Charles Stothard, published in Vetusta Monumenta, VI, I885, pl XVII. Photograph: () Society of Antiquaries of London.

Also at this time at least one fragment of the tapestry was removed (fig 4). By I864 this had found its way to the South Kensington Museum. ${ }^{12}$ Stothard's wife, Eliza, was accused of the crime. An I870 catalogue of that museum's 'textile fabrics' states that 'in the Vetusta Monumenta ... plate I7, shows ... a portion of this embroidery where the piece before us [the tapestry fragment] is figured ... From the writing under it, we learn that it was brought away from Bayeux by Mrs Stothard, when her husband was occupied in making drawings of that interesting record' ${ }^{13}$ However, the accusation against Eliza seems to be false: neither does plate XVII show the portion of the tapestry from which the fragment was taken, nor does the published version have any 'writing' about Eliza's theft. ${ }^{\mathrm{I}}$

In I88I, in a bizarre twist of events, Eliza was absolved of any part in the crime. A review of La Tapisserie de Bayeux by Jules Comte, published in The Times on 3I August I88I, called for Eliza to be forgiven: the reviewer stated that 'we are sorry that this lady should still be gibbeted in reputation ... for an offence which, however inexcusable, should now be forgotten'. The reason was clear: 'impelled by a feminine instinct, she cut a small piece of the border and took it away with her'. ${ }^{\text {I5 }}$

At the time this was written, it was assumed Eliza was dead; in fact she was in relatively good health, aged ninety-one. On 24 September I88I, The Times published a letter from Mrs Stothard's nephew, Charles Kempe, who considered it his 'duty to endeavour to vindicate' his aunt's 'character from an unmerited shame'. He reported 


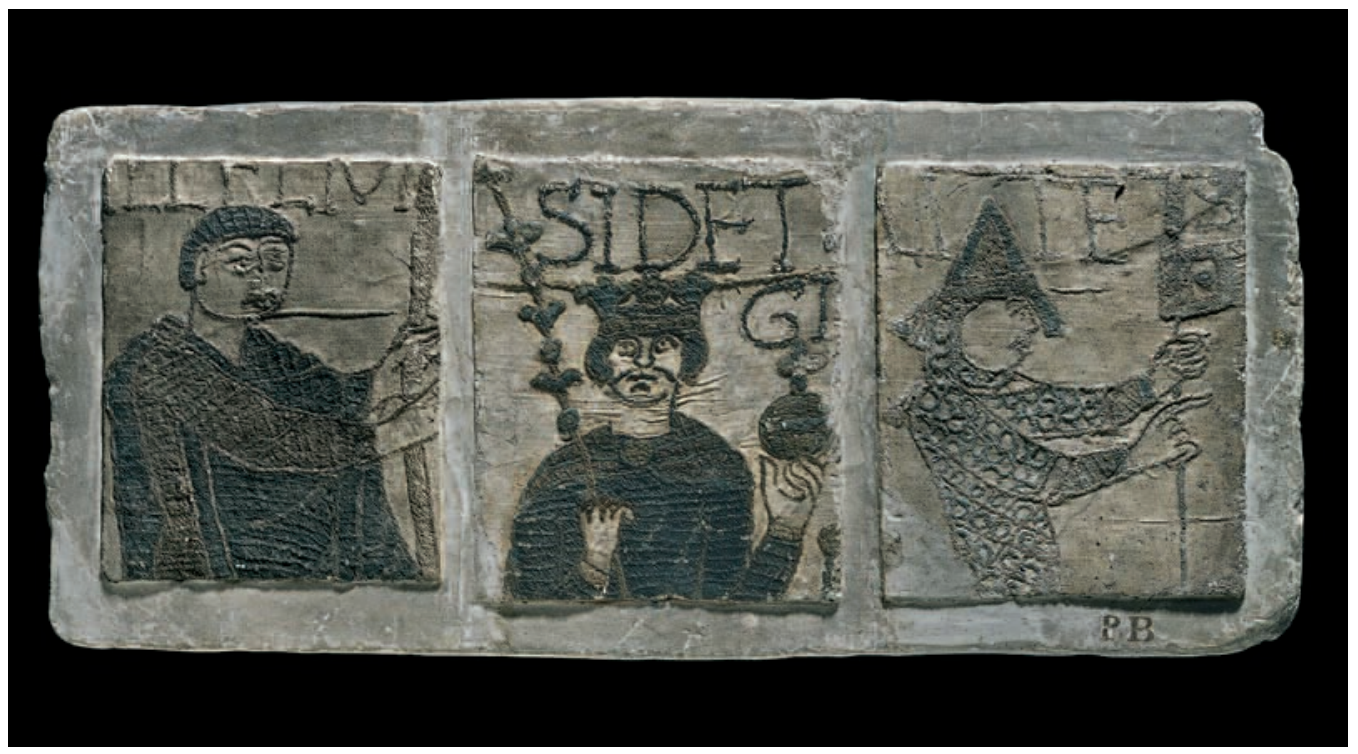

Fig 2. Plaster casts of details of the Bayeux Tapestry. Photograph: (C) The Trustees of the British Museum.

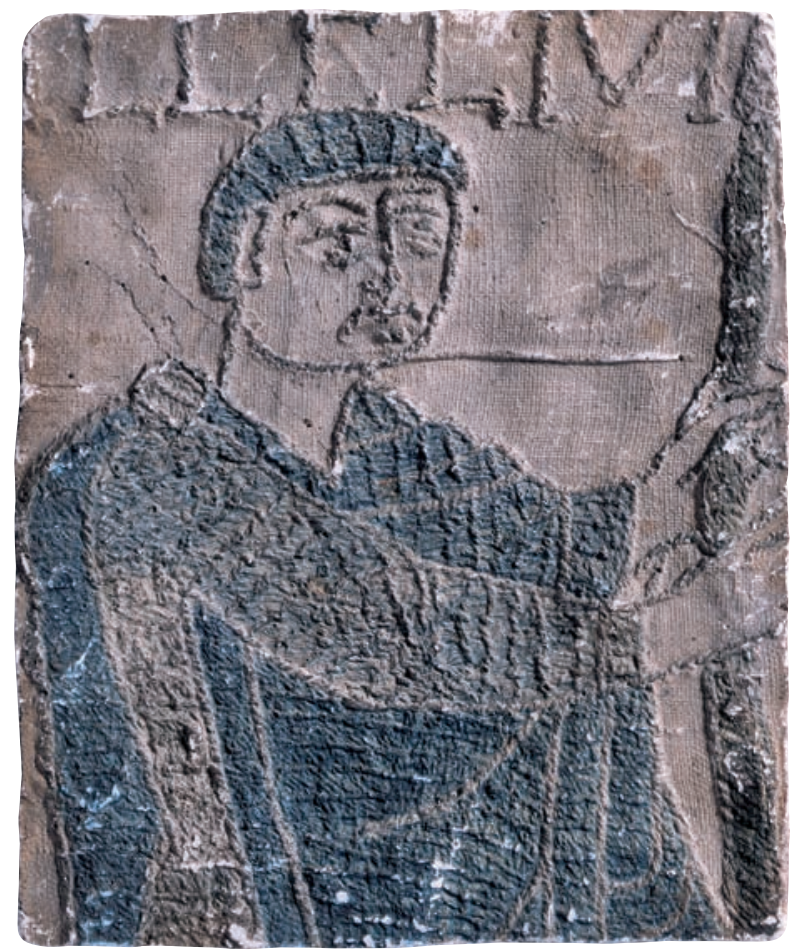

Fig 3. Plaster cast of detail of the Bayeux Tapestry. Photograph: (C) Society of Antiquaries of London. 


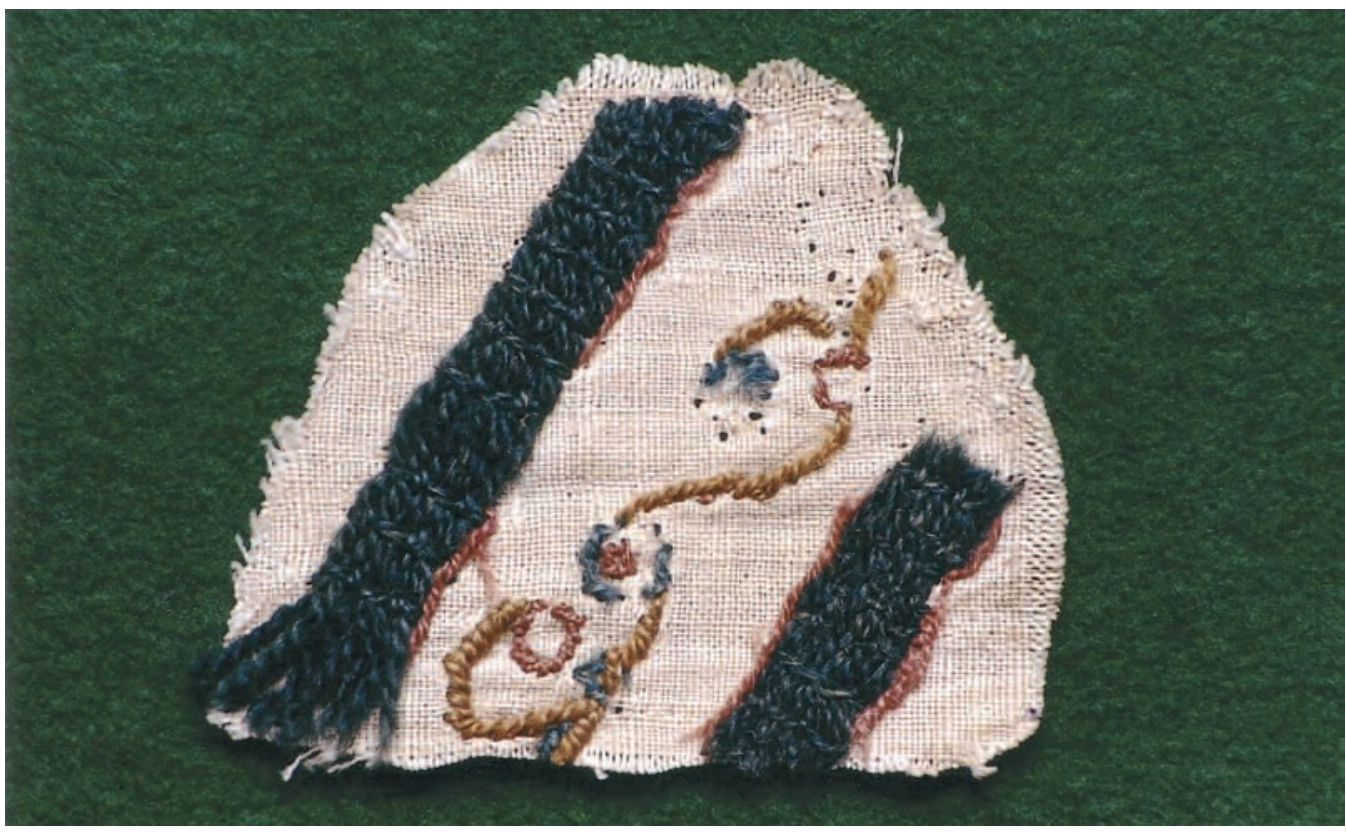

Fig 4. The fragment of the Bayeux Tapestry removed in about I8I6. Photograph: Vincent Cazin, Bibliothèque Municipale de Bayeux.

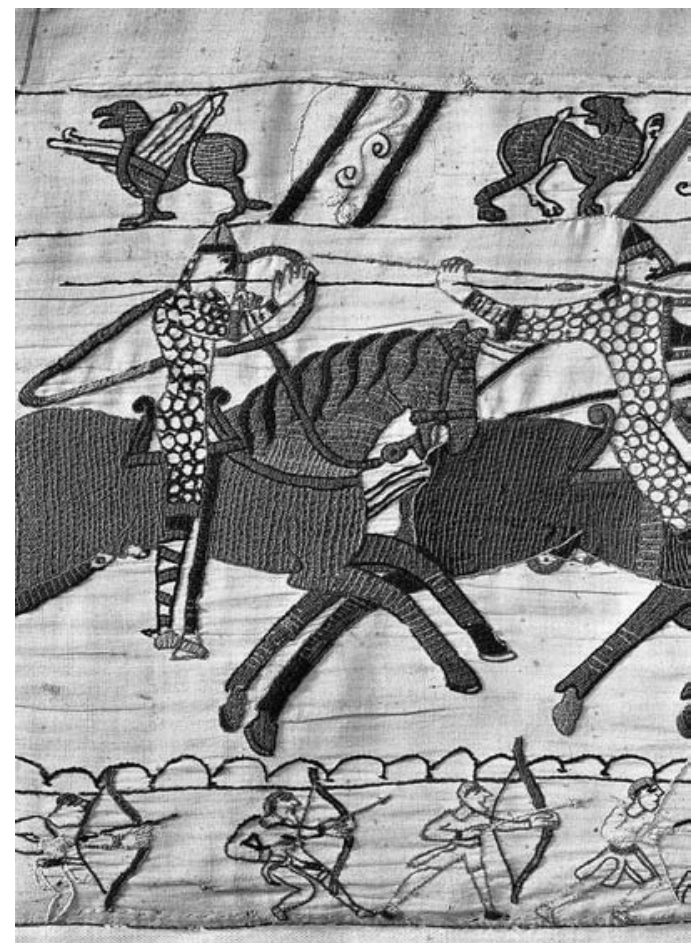

Fig 5. Detail of the Bayeux Tapestry showing the part from where the tapestry fragment was removed. Photograph: by special permission of the City of Bayeux. 
that Eliza 'well recollects' that prior to her visit to Bayeux (in I8I8) Charles Stothard 'was in possession of one or two small fragments of the tapestry, which he may have taken from the ragged portion and kept as a souvenir of his work'. Kempe went on to say: 'you may easily imagine the mingled feelings of indignation and amusement with which she [Eliza] has recently heard that the custodian of the tapestry at Bayeux informs visitors that "Madame confessed the theft upon her death bed". Thank God, she is still alive to tell the tale.' ${ }^{\text {' } 6}$

It therefore seems that Charles Stothard removed the tapestry fragment. This is implied in the 'Catalogue of the Doucean Museum', published in the Gentleman's Magazine of I836, which records that the fragment was 'cut off the end' (though it does not state by whom) and 'brought by' Charles Stothard 'to England in December I8I6' ${ }^{17}$ However, Eliza's story reminds us to be cautious when accepting recounted versions of events!

The history of the tapestry fragment thereafter is better known. Sometime between I8I6 and I82I the antiquarian Francis Douce 'acquired' it, together with casts of the tapestry, from Charles Stothard. Upon Douce's death, on 30 March I834, these artefacts were left to Sir Samuel Rush Meyrick, ${ }^{\mathrm{I} 8}$ who exhibited them in the 'Doucean Museum' at his home at Goodrich Court, Hereford. Following Meyrick's death, the fragment was bought by John Bowyer Nicholls; ${ }^{19}$ thereafter, on about 29 June 1864 , it was acquired by the South Kensington Museum for the princely sum of Is. $^{20}$ Nothing is known of the 'other' fragment referred to in Kempe's letter to The Times, but we do know that, soon after Charles Stothard's death, Eliza sold off his collection of antiquaries to Sir Gregory Page Turner, and this may have included part of the Bayeux Tapestry.

By August I87I South Kensington Museum planned to photograph the Bayeux Tapestry and sought the necessary permission to do so, ${ }^{21}$ but the municipal authorities in Bayeux objected, on the grounds that this might damage the hanging. A year later Henry Cole, the Director of the Museum, wrote to the Mayor of Bayeux - in French again requesting permission to photograph the tapestry, but this time offering the tapestry fragment as evidence of the museum's good intentions, and in the hope that it might be restored to its original position. ${ }^{22}$ The Mayor of Bayeux accepted this offer and the fragment was returned to Bayeux on I4 August I872. ${ }^{23}$ By this time the part of the tapestry from which the fragment had been cut had been restored (fig 5), ${ }^{24}$ and it was therefore displayed on its own. ${ }^{25}$

In recent times the fragment has rarely been displayed; instead it is archived at the Tapestry Museum in Bayeux. However, the authorities there are happy for the fragment to travel; in 2006 it was displayed as part of an exhibition on the Bayeux Tapestry at the National Museum of Denmark, Copenhagen, ${ }^{26}$ and it is hoped to exhibit it during a conference on the Bayeux Tapestry at the British Museum in July 2008.

\section{ACKNOWLEDGEMENTS}

This paper originated as a Ballot exhibit presented to the Society of Antiquaries of London on 7 June 2007. It is indebted to the work of Carola Hicks, FSA, published in her recent book, The Bayeux Tapestry: the life story of a masterpiece (2006). The author would also like to thank Sylvette Lemagnen (Conservateur de la Tapisserie de Bayeux), Bernard Nurse, FSA (Librarian of the Society of Antiquaries of London), and the staff 
of the Victoria and Albert Museum, in particular Peta Motture, FSA, and James Sutton, whose help has been invaluable.

\section{NOTES}

I. Seemingly made so posthumously, on io July I82I: SAL, Council Minutes, IV, 382.

2. The motion was proposed by Joseph Jekyll, and seconded by Sir Charles Blagden; Samuel Lysons was in the Chair: SAL, Council Minutes, IV, 3II, 8 July I8I6.

3. SAL, Minutes, XXXIII, 75I, 4 July I8I6.

4. Gurney 1817. Gurney's obituary in Proc Soc Antiq London, 2nd ser, 3 (I864-7), II 2 (24 Apr 1865), states that 'his visit to the Bayeux Tapestry, in I8I4, gave rise to our Society's mission of the younger Stothard to Bayeux in that year, to make the elaborate copy [of the tapestry]'.

5. Montfaucon I729; Montfaucon 1730.

6. The Bayeux Tapestry had been housed here since 1804 .

7. Monies paid to Charles Stothard: $£$ II 5 on I8 Feb I8I7 (SAL, Council Minutes, IV, 323), £33 Is $6 \mathrm{~d}$ on II June I8I7 (ibid, 328), though it is not certain this was for work drawing the Bayeux Tapestry; £226 IIs 6d on 24 Feb I8I8 (ibid, 333), which also included the drawing of five seals; $£$ I $856 \mathrm{~s}$ $6 \mathrm{~d}$ on 2 March I8I9 (ibid, 347), although again it is not certain this was for work drawing the Bayeux Tapestry.

8. Stothard I885.

9. SAL, Council Minutes, IV, 349, 4 May I8I9.

IO. Ibid, 37I, 2I June I820.

II. British Museum casts: BM I873-8, acquisition no. I878, IIOI.379 (donated by Augustus W H Meyrick in 1878); Society of Antiquaries of London cast: cat. no. I09.

I2. Now the Victoria and Albert Museum.

13. Rock I870, 6-7, no. 675 .

I4. Stothard I885, pl XVII. Possibly the edition of Vetusta Monumenta from which Rock worked had this information scribbled on to it, but this no longer seems to be in the V\&A's collection.

15. The Times, 3I Aug I88I, IO.

I6. The Times, 24 Sept I88I, Io. On the same date Charles Kempe also wrote to the South Kensington Museum (V\&A ED84/I67, 504I), requesting its help to correct 'the placard at Bayeux', which it did. Frank R Fowke had to explain (to his superiors) how it came to be that Eliza
Stothard was accused of cutting off a portion of the tapestry; the information on the placard at Bayeux had been based upon information provided by South Kensington Museum. Fowke wrote, in a now unhelpfully fragmented document, that 'the letter written to the authorities at Bayeux was based on the "Textile Fabrics in the South Kensington Museum"'; he added: 'Father Rock probably intended to $\operatorname{mar}[\ldots]$ inscriptions on the frame of the fragment [...] museum his authority' (V\&A ED84/I67, 504I).

17. Gent's Mag I836, 38I, cat. no. 3 .

I8. Sir Samuel Rush Meyrick died on $2 \mathrm{Apr}$ I848.

I9. John Bowyer Nicholls died on I9 Oct I863.

20. V\&A ED84/36, 2 Io lists, under purchases for I2 July I864, 'a piece of the Bayeux tapestry, framed. Two coloured plaster casts from Bayeux tapestry ... purchased at Mr Bowyer-Nicholl's sale'. V\&A I863-77, IOI, describes the tapestry fragment (object no. 675-I864) as a 'fragment of linen embroidery in frame, with inscription stating it to be a portion of the Bayeux Tapestry'. Its 'date of receipt from [the Museum's] stores' was 29 June I864. It was 'received' from 'Bowyer Nicholl's Sale' at a cost of 'sI/-'. Its 'date of minute for purchase' was I2 July I 864.

2I. V\&A ED84/167, 3084I/7I (letters from Joseph Cundall, dated 2 Aug I87I, and Lord G J Duncombe, dated Io Aug I87I).

22. V\&A ED84/167 (letter from Henry Cole, dated Io Aug I872) states: 'Désireuses de montrer combien Elles sont sensibles à la sympathie courtoise dont les autorités auxquelles la garde de ces Tapisseries a été confiée ont donné des preuves si nombreuses aux agents chargés par la direction du Musée de faire des réproductions photographiques de ces chefs-d'oeuvre, Leurs Seigneuries viennent prier la Municipalité de la Ville de Bayeux de vouloir bien accepter le morçeau de Tapisserie en question comme un témoignage de leur reconnaissance, dans l'espoir qu'il sera possible de le remettre dans la place qu'il occupait lorsqu'il a été enlevé. Si vous voulez avoir 
la bonté, Monsieur, de soumettre cetter offer à la Municipalité de Bayeux, et me faire connaitre le plus tôt possible, leur décision à ce sujet, Monsieur Fowke, attaché à l'administration du Musée, qui doit quitter Londres I4 courant, sera chargé spécialement d'apporter à Bayeux ce précieux spécimen artistique, et de le présenter personnellement à la personne que vous voudrez bien désigner'.

23. V\&A I863-77, IOI, states that the tapestry fragment was 'returned to Bayeux' on 'I4 August I872'.
24. This restoration work seems to have taken place between I 838 and I842: Hicks 2006, I38.

25. This was to have the caption (in French): 'a piece of the Tapestry was removed by Mme Stothard while her husband was busy copying it in I8I6. This fragment, acquired by the Kensington Museum, has been returned'.

26. 'Bayeux tapetet - en broderet krønike fra vikingetiden', 2I Jan to 30 Apr 2006.

\section{BIBLIOGRAPHY}

\section{Abbreviations}

$\mathrm{BM}$

SAL

V\&A
British Museum, London

Society of Antiquaries of London

Victoria and Albert Museum, London

\section{Primary sources}

BM 1873-8: Register of Antiquities, III, Feb I873-Jan I878

SAL, Minute Book, XXXIII, 7 Nov I8II-Feb I8I7

SAL, Council Book, IV, Io Jan I804-30 July I 829

The Times, 3I Aug I88I

\section{Secondary sources}

Gent's Mag 1836. 'Catalogue of the Doucean Museum at Goodrich Court, Herefordshire', Gent's Mag, Io6/2, 378-84

Gurney, H I8I7. 'Observations on the Bayeux Tapestry', Archaeologia, 18, 359-70

Hicks, C 2006. The Bayeux Tapestry: the life story of a masterpiece, London

Montfaucon, B de 1729. Les Monumens de la Monarchie française, I, Paris
The Times, 24 Sept I88I

V\&A 1863-77: Museum Register, No. 3, Science and Art Department

V\&A ED84/36, Précis of the Board Minutes of the Science and Art Department, 8 July I863-23 Dec I869

V\&A ED84/167

Montfaucon, B de I730. Les Monumens de la Monarchie française, II, Paris

Rock, D i870. Textile Fabrics: a descriptive catalogue, London

Stothard, C A I885. 'The tapestry of Bayeux', Vetusta Monumenta, VI, pls I-XVII, London (published I82 I-3, bound I885) 